\title{
Feedbacks of $\mathrm{CO}_{2}$ dependent dissolved organic carbon production on atmospheric $\mathrm{CO}_{2}$ in an ocean biogeochemical model
}

\section{Modeled $\mathrm{CO}_{2}$ feedbacks}

L. A. Bordelon-Katrynski and B. Schneider

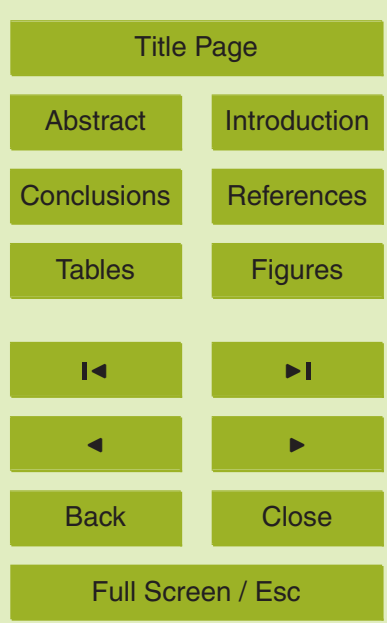

Printer-friendly Version

Interactive Discussion 


\section{Abstract}

We use an ocean biogeochemical model to test whether a potential $\mathrm{CO}_{2}$ dependence of dissolved organic carbon (DOC) production may have an influence on marine carbon sequestration via particle aggregation and so may represent a potentially larger ocean sink for anthropogenic $\mathrm{CO}_{2}$. The hypothesis is based on mesocosm experiments that have shown enhanced carbon uptake by phytoplankton when more $\mathrm{CO}_{2}$ is available, and where the extra carbon was probably directly routed into DOC instead of the particulate phase. Sensitivity experiments are carried out where phytoplankton exudation of DOC is systematically increased with and without a parallel rise in atmospheric $\mathrm{CO}_{2}$. We find that under a fourfold increase of the DOC formation rate, there is a slight reduction of global particle export, which results in a shallower turnover of nutrients and carbon. As a consequence, a positive feedback loop develops, such that the ocean becomes a weak source of $\mathrm{CO}_{2}$ to the atmosphere. The effect is amplified under high $\mathrm{CO}_{2}$ conditions due to the decreased $\mathrm{CO}_{2}$ buffer capacity of the ocean, however, it is rather low compared to the total anthropogenic perturbation. The positive feedback is in contrast to a very similar study, where a slight stimulation of particle export was found. Therefore, we conclude that the sign of the feedback depends on the actual pathway the extra carbon is taking and on the overall background conditions of marine primary production and ocean circulation.

\section{Introduction}

The ocean has taken up nearly $1 / 3$ of anthropogenic $\mathrm{CO}_{2}$ emissions since preindustrial times (Sabine et al., 2004), resulting in an overall $\mathrm{pH}$ drop of the global surface waters from 8.21 to 8.10 today (Doney et al., 2009). This decline of $-0.1 \mathrm{pH}$ units corresponds to a $30 \%$ increase in hydrogen ions in seawater. By the end of this century the sur-
BGD

9, 7983-8011, 2012

Modeled $\mathrm{CO}_{2}$ feedbacks

L. A. Bordelon-Katrynski and B. Schneider

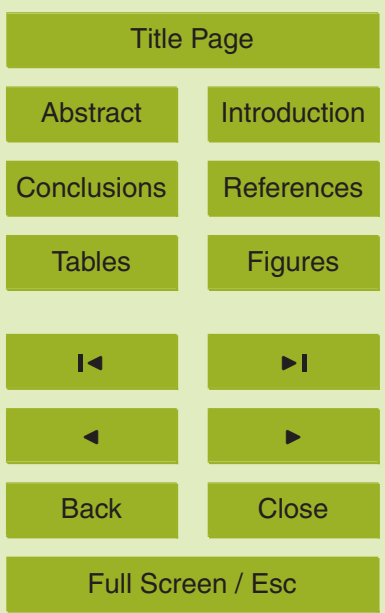

Printer-friendly Version

Interactive Discussion 
Caldeira and Wicket, 2003), which my have severe consequences on marine organisms and the cycling of elements (Doney et al., 2009).

Model results have shown that in recent decades the oceanic sink for anthropogenic carbon reduced from 30 to $25 \%$ of the total emissions, while the airborne fraction 5 increased from about 40 to $45 \%$ (Canadell et al., 2007). Consequently, it is presently unclear whether the ocean can continue its current rate of carbon uptake (Corbiere et al., 2007; Metzl et al., 1999; McKinley et al., 2011). A reduction in the efficiency of the ocean carbon sink, for example caused by reduced solubility of $\mathrm{CO}_{2}$ in warming surface waters, would provide a positive feedback on the atmosphere and thus anthropogenic 10 climate change (Friedlingstein et al., 2006). On the other hand, a continuing uptake of $\mathrm{CO}_{2}$ by the ocean (Roy et al., 2011) causes a further $\mathrm{pH}$ decline that will affect organisms that are sensitive to $\mathrm{CO}_{2}$ and/or $\mathrm{pH}$ changes, which in turn may also feed back on atmospheric $\mathrm{CO}_{2}$ and thus climate (Doney et al., 2009).

The biological carbon pump describes the photosynthetic conversion of dissolved 15 inorganic carbon (DIC) at the sea surface into particulate organic matter, which sinks through the water column where it is partly or entirely remineralized. This pump sequesters carbon into the deep ocean, allowing $\mathrm{CO}_{2}$ from the atmosphere to replace the carbon exported by particle flux (Volk and Hoffert, 1985). When transported (upwelled) back to the sea surface, the $\mathrm{CO}_{2}$ rich deep water masses act as a source of $\mathrm{CO}_{2}$ to the atmosphere. Marine phytoplankton have been documented to take up carbon and nitrogen in a fixed ratio, which in today's ocean equals 106:16 (6.6) (Redfield et al., 1963). However, elevated $\mathrm{CO}_{2}$ levels have been found to affect phytoplankton by increasing DIC uptake during photosynthesis, and thus may raise C:N over the Redfield Ratio (Raven and Johnston, 1991; Riebesell et al., 1993; Hein and Sand-Jensen, 1997; 25 Gordillo et al., 2003; Hutchins et al., 2007). In mesocosm experiments under elevated $\mathrm{CO}_{2}$ levels, natural communities of phytoplankton have shown to metabolize more carbon without increasing their nitrogen uptake (Riebesell et al., 2007). For example, a C:N uptake ratio of 8.0 was found under three times current atmospheric $\mathrm{CO}_{2}$ conditions, significantly exceeding the classical Redfield Ratio. However, since the elevated C:N

\section{BGD}

9, 7983-8011, 2012

Modeled $\mathrm{CO}_{2}$ feedbacks

L. A. Bordelon-Katrynski and B. Schneider

Title Page

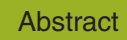

Introduction

Conclusions

Tables

References

Figures

14

$\rightarrow$

4

Back

Close

Printer-friendly Version

Interactive Discussion 
ratios were not immediately found in the particulate material, the fate of the excess carbon remains unknown. It was hypothesized that increased formation of dissolved organic carbon (DOC), which was rapidly transferred into transparent exopolymer particles (TEP), could explain the observed carbon loss (Riebesell et al., 2007). TEP par5 ticles, mostly made of sugars, are known to be sticky and aid in particle aggregation (Passow, 2002; Engel et al., 2004). Therefore, it was proposed that an increased formation and thus concentration of DOC and TEP would intensify particle aggregation and sinking, so that the excess carbon would become sequestered in the deep ocean (Arrigo, 2007), providing a negative feedback on atmospheric $p \mathrm{CO}_{2}$.

10 The hypothesis of carbon overconsumption has been tested in ocean biogeochemical models, where it was found that carbon export (EP) and thereby air-sea $\mathrm{CO}_{2}$ flux could indeed be increased via elevated $\mathrm{C}: \mathrm{N}$ ratios of particulate organic matter (Schneider et al., 2004; Oschlies et al., 2008; Tagliabue et al., 2011). But compared to the total anthropogenic perturbation, the effect of an extra storage of carbon in the ocean 15 (34-70 GtC) on the atmospheric $p \mathrm{CO}_{2}$ is rather marginal. However, according to the mesocosm study of Riebesell et al. (2007) the extra carbon was not immediately transferred to the sinking particles, but rather routed via DOC and TEP to the particle pool. Accordingly, the impact of a $25 \%$ increase in NPP via DOC formation on particle export was estimated by Tagliabue et al. (2011), who found that in the absence of a change in the C:N ratio of particle fluxes, there is indeed a small stimulation of carbon export $(+4 \%)$.

In the present study we will address the question of the impact of a $\mathrm{CO}_{2}$-induced higher DOC exudation rate on particle flux via aggregation. Therefore, we use an ocean biogeochemical model, which includes particle aggregation under fixed element ratios, and where DOC formation will be coupled to the atmospheric $p \mathrm{CO}_{2}$. Our study is similar to Tagliabue et al. (2011), but it differs in several aspects with regard to (1) the way the extra carbon is routed into DOC, (2) the sensitivity to atmospheric $p \mathrm{CO}_{2}$, and (3) the $\mathrm{CO}_{2}$ scenario which was used. Although reaching a very similar stimulation of DOC
BGD

9, 7983-8011, 2012

Modeled $\mathrm{CO}_{2}$ feedbacks

L. A. Bordelon-Katrynski and B. Schneider

Title Page

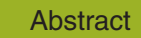

Introduction

Conclusions

Tables

References

Figures

14

DI

4

Back

Close

Full Screen / Esc

Printer-friendly Version

Interactive Discussion 
formation (approx. $20 \%$ of total carbon fixation via NPP), we find a reduction of particle export flux. This is in contrast to Tagliabue et al. (2011) and will be discussed in detail.

\section{Model and experiments}

\subsection{Model description}

5 The PISCES model simulates the cycling of the major nutrients that control phytoplankton growth: silica, nitrate, ammonium, phosphate, and iron as well as dissolved inorganic carbon (DIC), dissolved organic carbon (DOC) and oxygen (Aumont et al., 2006). The model has two phytoplankton size classes (small and large), representing nanophytoplankton and diatoms, as well as two zooplankton size classes (small and large), representing microzooplankton and mesozooplankton. For all species the C:N:P ratios are assumed constant (122:16:1; Anderson and Sarmiento, 1994), while the internal ratios of $\mathrm{Fe}: \mathrm{C}, \mathrm{Chl}: \mathrm{C}$, and $\mathrm{Si}: \mathrm{C}$ of phytoplankton are predicted by the model. There are two size classes of detrital POC, small and large. The small size class sinks at a fixed rate of $2 \mathrm{mday}^{-1}$ while the large particles accelerate with depth from 50 to 200 m day $^{-1}$ (Aumont and Bopp, 2006). In the model, dissolved organic carbon forms primarily from nanophytoplankton and diatom excretion, but also from zooplankton growth, zooplankton grazing on phytoplankton and POC and by the decay of POC. DOC is lost through particle aggregation, which occurs via turbulent shear and differential settling of particles. The detailed equations governing particle collision are given in Gehlen et al. (2006). Furthermore, DOC decays on a timescale from weeks to years. In order to simulate bacterial activity, degradation of DOC is dependent on temperature and nutrient availability (Aumont and Bopp, 2006).

The physical forcing fields to run the ocean biogeochemical model are obtained from the OPA 9.2 stand-alone ocean model. The model has a horizontal resolution of 2 degrees (lon $\times$ lat) at the poles and a finer resolution towards the tropics reaching 0.5 degrees in latitude at the equator. In the vertical it has 30 levels increasing from $10 \mathrm{~m}$

\section{BGD}

9, 7983-8011, 2012

Modeled $\mathrm{CO}_{2}$ feedbacks

L. A. Bordelon-Katrynski and B. Schneider

Title Page

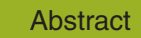

Introduction

Conclusions

Tables

References

Figures

14

$\rightarrow 1$

4

Back

Close

Full Screen / Esc

Printer-friendly Version

Interactive Discussion 
thickness in the top $100 \mathrm{~m}$ to $500 \mathrm{~m}$ vertical extension at depth. The forcing fields to drive the ocean model are described in Aumont and Bopp (2006). We use a climatological 5-day forcing, repeating each year, so that ocean circulation exhibits seasonal, but no interannual or longer-term variability.

5 In the spinup and the control simulation atmospheric $\mathrm{CO}_{2}$ is fixed at the preindustrial level of $284.6 \mathrm{ppm}$. The carbonate chemistry follows simplified OCMIP protocols (Aumont and Bopp, 2006).

\subsection{Mean state}

The Atlantic Meridional Overturning Circulation (AMOC; not shown) exhibits the typical pattern of a clockwise circulation in the upper $2500 \mathrm{~m}$ (NADW) and a counter clockwise flow below (AABW). The maximum of the NADW streamfunction lies at $40-45^{\circ} \mathrm{N}$ and amounts to $15.75 \mathrm{~Sv}\left(1 \mathrm{~Sv}=10^{6} \mathrm{~m}^{3} \mathrm{~s}^{-1}\right)$, which is in good agreement with observations (Schmitz and McCartney, 1993; Talley et al., 2003; Kanzow et al., 2010;). The boundary between NADW and AABW lies at $2500 \mathrm{~m}$, which is shallower compared to $3000 \mathrm{~m}$ depth from observations (Tomczak and Godfrey, 2003) and other model studies (Lozier et al., 2010). The maximum strength of the Atlantic bottom water cell corresponds to $7.8 \mathrm{~Sv}$ at $12^{\circ} \mathrm{N}$, which also agrees well with observations and other models (Schmitz and McCartney, 1993; Lozier et al., 2010). The spatial distribution of temperature and salinity is well reproduced by the model as shown in a Taylor Diagram (Fig. 1), where a normalized standard deviation of one and a correlation coefficient of $R=1$ would indicate a perfect fit between model results and observational data. The agreement of $T$ and $S$ is at least as good as in typical IPCC simulations (Schneider et al., 2007).

Nutrient and carbon (DIC) distributions are also well reproduced with correlation coefficients above $R=0.9$, whereas oxygen and total alkalinity agree less well. The

latter has already been shown to be difficult to reconcile in ocean biogeochemical models (Gehlen et al., 2007), probably due to large uncertainties in the sources and sinks of particulate inorganic carbon $\left(\mathrm{CaCO}_{3}\right)$. Net primary production (NPP) shows the weakest match with $R=0.67$ ), however, this is considerably better than in fully
BGD

9, 7983-8011, 2012

Modeled $\mathrm{CO}_{2}$ feedbacks

L. A. Bordelon-Katrynski and B. Schneider

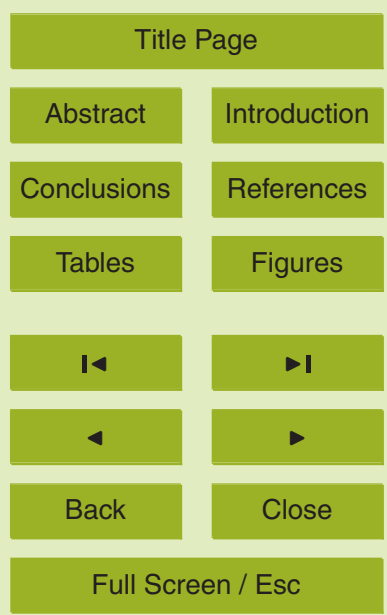

Printer-friendly Version

Interactive Discussion 
coupled models (Schneider et al., 2008). Interestingly, the distribution of the degree of calcite saturation Omega $\left(\mathrm{CO}_{3}^{2-} / \mathrm{CO}_{3}^{2-}\right.$ sat $)$ has a high correlation $(R=0.98)$ and only a weak bias, while the depth of the calcite saturation horizon $(\mathrm{CSH})$ matches less well $(R=0.83)$. This is probably caused by the large bias in the $\mathrm{CSH}$, which is on the order 5 of $-20 \%$, and the fact that a 2-D distribution has less degrees of freedom.

The fields of oxygen and apparent oxygen utilization (AOU) also exhibit correlations near $R=0.9$, however, the distribution of oxygen minimum zones (OMZs; e.g., Stramma et al., 2008) is not very well reproduced (not shown). Generally the model oxygen concentrations are too high, corresponding to an overestimation of $15 \%$ on 10 global average. Especially in the OMZs of the Atlantic and the Eastern Tropical Pacific oxygen concentrations are considerably too high. The overestimated upper water column oxygen values are a possibly caused by too weak downward mixing, whereas the high oxygen concentrations in the deep South Atlantic and Pacific are probably caused by too strong ventilation from the South. Only in the Atlantic from $60^{\circ} \mathrm{N}$ to $40^{\circ} \mathrm{S}$ below 15 about $2000 \mathrm{~m}$ depth oxygen is by about $20-50 \mu_{\text {moll }}^{-1}$ too low, most probably due to the too shallow overturning cell in the North Atlantic.

\subsection{Sensitivity experiments}

To assess the sensitivity of the ocean carbon sink to $\mathrm{CO}_{2}$-induced changes in the DOC exudation rate of marine phytoplankton, we calculate a transfer function based 20 on the increase of the C:N uptake ratio observed in the mesocosm studies by Riebesell et al. (2007). Therefore, we consider that in the pre-industrial control simulation, our model has a net primary production (NPP) of around $30 \mathrm{GtCyr}^{-1}$. DOC exudation by phytoplankton is set to $5 \%$ of the model NPP, which means that $1.5 \mathrm{GtCyr}^{-1}$ is exudated as DOC. In the mesocosm experiment of Riebesell et al. (2007) a C:N uptake 25 ratio of 8.0 was found under almost $4 \times$ preindustrial $\mathrm{CO}_{2}$ concentrations $(\sim 3 \times$ modern $p \mathrm{CO}_{2}$ ), which corresponds to a $20 \%$ increase relative to a Redfield $\mathrm{C}: \mathrm{N}$ ratio of 6.6. A $20 \%$ increase of our modeled NPP would amount to about $36 \mathrm{GtCyr}^{-1}$, which

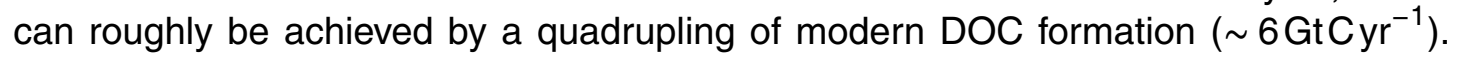

\section{BGD}

9, 7983-8011, 2012

Modeled $\mathrm{CO}_{2}$ feedbacks

L. A. Bordelon-Katrynski and B. Schneider

Title Page

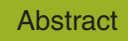

Introduction

Conclusions

Tables

References

Figures

14

- I

4

Back

Close

Full Screen / Esc

Printer-friendly Version

Interactive Discussion 
Consequently, we run a standard $\mathrm{CO}_{2}$ scenario with a $1 \% \mathrm{CO}_{2}$ increase per year, reaching $4 \times \mathrm{CO}_{2}$ after $140 \mathrm{yr}$, and directly link the $\mathrm{DOC}$ exudation rate to the rate of $\mathrm{CO}_{2}$ increase, such that at the end of the simulation DOC formation from phytoplankton exudation amounts to $20 \%$ of global NPP.

\section{$5 \quad$ 2.3.1 Control}

The model was spun up over $6000 \mathrm{yr}$ using the standard setup of the NEMO V3.2 model under the physical forcing fields explained above. This run was continued with constant preindustrial $\mathrm{CO}_{2}$ over $500 \mathrm{yr}$ to serve as control simulation.

\subsubsection{CDOC}

10 In this experiment, both the $\mathrm{CO}_{2}$ and DOC formation rate are increased by $1 \%$ every year for $140 \mathrm{yr}$. The quadrupled values are kept constant until the simulation reaches $500 \mathrm{yr}$. This experiment combines the affect of high DOC formation as well as high atmospheric $\mathrm{CO}_{2}$ levels on the carbon cycle.

\subsection{3 $\mathrm{CO}_{2}$}

15 In the $\mathrm{CO}_{2}$ experiment, only the atmospheric $\mathrm{CO}_{2}$ is increased by $1 \%$ every year until it is quadrupled and then it is kept constant until the year 500. The aim of this experiment is to isolate the DOC affect at high $\mathrm{CO}_{2}$ levels by calculating $\mathrm{CDOC}-\mathrm{CO}_{2}$.

\subsubsection{DOC}

In the DOC experiment, only the production of DOC is quadrupled by increasing the phytoplankton excretion rate by $1 \%$ every year so that the excretion flux increases from $5 \%$ to $20 \%$ at the end of the $140 \mathrm{yr}$ period, staying constant at this value until year 500 . The purpose of this experiment is to isolate the $\mathrm{DOC}$ affects at low background $\mathrm{CO}_{2}$ (DOC-Control) and to compare this with the DOC effect under high $\mathrm{CO}_{2}\left(\mathrm{CDOC}-\mathrm{CO}_{2}\right)$,

\section{BGD}

9, 7983-8011, 2012

Modeled $\mathrm{CO}_{2}$ feedbacks

L. A. Bordelon-Katrynski and B. Schneider

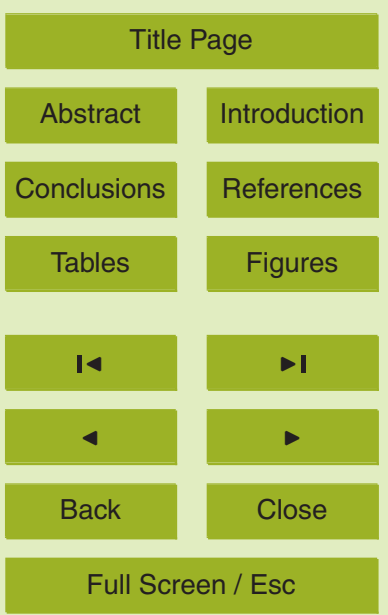

Printer-friendly Version

Interactive Discussion 
which in turn corresponds to the $\mathrm{CO}_{2}$ effect at high DOC formation (CDOC-DOC). All experiments are outlined in Table 1.

BGD

9, 7983-8011, 2012

\section{Results}

\subsection{Impact of $\mathrm{CO}_{2}$-sensitive DOC formation on ocean carbon and nutrient cycling}

With a four times higher rate of DOC formation, the global inventory of DOC increases only marginally by about $2 \%$ to $43.8 \mathrm{GtC}$, independent of the atmospheric $\mathrm{CO}_{2}$ values (Table 2). The highest accumulation of DOC is found in the subtropical gyres (Fig. 2a, b), where DOC degradation is nutrient limited (see discussion in Tagliabue et al., 2011). 10 At the same time the global POC inventory decreases by about $4 \%$ to $1.04 \mathrm{GtC}$ (Table 2), showing that in our model higher DOC formation and a slightly larger DOC inventory are at the expense of POC rather than fostering particle aggregation. Consequently, the global particle export flux reduces by roughly $5 \%$, although regionally there are strongly enhanced POC-fluxes, for example in the low productive/low export subtropical gyres (Fig. 2c, d). Especially in the Pacific on the borders of the subtropical gyres, an up to $5 \%$ amplified POC-flux reaches down into the deep ocean, although offset by up to $20 \%$ reduced POC-flux at higher latitudes (Fig. 2c). Interestingly, in the Atlantic a higher POC-flux is only found at the poleward sides of the subtropical gyres (Fig. 2d), probably due to the overall low $\mathrm{NO}_{3}$ concentrations in the tropical surface waters. The changed DOC cycling also affects nutrient distributions with a tendency of shallow water nitrate accumulation, which reduces the vertical $\mathrm{NO}_{3}$ gradient. Especially around and directly below the subtropical gyres $\mathrm{NO}_{3}$ accumulates under higher DOC formation (Table 2, Fig. 2e, f). This shallower turnover of nitrogen stimulates global net primary production (NPP), which is amplified by about $10 \%\left(+3 \mathrm{GtCyr}^{-1}\right)$, proportion-
Modeled $\mathrm{CO}_{2}$ feedbacks

L. A. Bordelon-Katrynski and B. Schneider

Title Page

Abstract

Introduction

Conclusions

Tables

References

Figures

14

$\rightarrow$

4

Back

Close

\section{Full Screen / Esc}

Printer-friendly Version

Interactive Discussion ble 2). Only about $1 \mathrm{GtCyr}^{-1}$ of the extra NPP is accounted for in the new production, 
showing that regenerated production, which according to Dugdale and Goering (1967) is based on $\mathrm{NH}_{4}$ uptake, is dominant. NPP stimulation due to the shallower carbon and nutrient turnover takes place mostly in the high productive regions of the North Atlantic, the eastern boundary upwelling regions of the tropical and subtropical Atlantic 5 and Pacific. However, there is also a considerable increase of NPP on the borders of the subtropical gyres, fueled by the higher availability of nitrogen as shown in Fig. 3. In experiment $\mathrm{CO}_{2}$, the cycling of organic carbon and major nutrients remains largely unaffected, because organic matter turnover is not directly sensitive to $\mathrm{CO}_{2}$. However, in the experiment combining high $\mathrm{DOC}$ and $\mathrm{CO}_{2}$ there is a slight positive $\mathrm{CO}_{2}$ effect $10\left(+0.3 \mathrm{GtCyr}^{-1}\right)$ on NPP (Fig. 3e). This is probably due enhanced iron availability after reduced scavenging by particulate inorganic carbon (PIC) under ocean acidification. This effect will be explained in more detail in the discussion section. Interestingly, there is no stronger export in the high productive regions experiencing NPP stimulation, but rather a drop in EP (Fig. 4b, d). The strongest export increase under high DOM forma15 tion can be found on the borders of the subtropical gyres and in the Western Pacific Warm Pool (WPWP), whereas EP remains largely unaffected by the pure $\mathrm{CO}_{2}$ forcing (Fig. 4e).

\subsection{Ocean carbon storage}

In both experiments in which $\mathrm{CO}_{2}$ is increased there is a flux of carbon from the atmosphere into the ocean, as can be expected due to the positive partial pressure difference (Fig. 5). However, in the experiments with elevated DOC formation by phytoplankton, there is a net loss of $\mathrm{CO}_{2}$ to the atmosphere, caused by the shallower turnover of nitrogen and carbon. When calculating the global cumulative net air-sea $\mathrm{CO}_{2}$ flux over the 500 model years, in experiment DOC this results in a net loss of $28 \mathrm{GtC}$ to the atmosphere, while under simultaneously elevated $\mathrm{CO}_{2}$ concentrations this effect rises to $37 \mathrm{GtC}$, representing a positive feedback on atmospheric $\mathrm{CO}_{2}$ (Table 2, Fig. 5). This amplification of carbon loss to the atmosphere at high $\mathrm{CO}_{2}$ is caused by the reduced buffer capacity of the surface ocean.

BGD

9, 7983-8011, 2012

Modeled $\mathrm{CO}_{2}$ feedbacks

L. A. Bordelon-Katrynski and B. Schneider

Title Page

Abstract

Introduction

Conclusions

Tables

References

Figures

14

$\rightarrow$

4

Back

Close

Full Screen / Esc

Printer-friendly Version

Interactive Discussion 
Due to the spatial pattern of the sea-air partial pressure difference of $\mathrm{CO}_{2}\left(\Delta p \mathrm{CO}_{2}\right)$, there is a constant exchange of carbon between atmosphere and ocean (Takahashi et al., 2002,2009). In general, the ocean takes up carbon from the atmosphere at intermediate to high northern latitudes and the southern mid-latitudes, while there is 5 constant outgassing into the atmosphere primarily in the tropics, which is well represented by our model simulation (Fig. 6 top; Mikaloff-Fletcher et al., 2007; Takahashi et al., 2009). At preindustrial times, the annual exchange was almost neutral with a small flux of about $0.4 \mathrm{GtC} \mathrm{yr}^{-1}$ into the atmosphere, balancing the river input of carbon into the ocean (Takahashi et al., 2009). An increase of the atmospheric $p \mathrm{CO}_{2}$ due 10 to anthropogenic emissions forces a stronger $\mathrm{CO}_{2}$ flux into the ocean due to the more positive air-sea $\Delta p \mathrm{CO}_{2}$. As shown in Fig. 5, assuming a $\mathrm{CO}_{2}$-related fourfold increase in DOC formation, the total uptake of anthropogenic carbon is reduced. The differences in carbon pathways between the experiments of high DOM formation (CDOC) and $\mathrm{CO}_{2}$ only $\left(\mathrm{CO}_{2}\right)$ is shown in Fig. 6 at the bottom, highlighting areas of stronger uptake and outgassing in $\mathrm{CDOC}$ relative to $\mathrm{CO}_{2}$. Especially the equatorial borders of the subtropical gyres in the Pacific are characterized by increased carbon uptake by the ocean due to the higher NPP (Fig. 3) caused by higher nitrate availability (Fig. 2e). However, this extra carbon is quickly remineralized around and below the subtropical gyres and entrained as DIC into the equatorial current system, where it upwells near the equator and then escapes back into the atmosphere. As this DIC transport is accompanied by $\mathrm{NO}_{3}$, its pathway can be tracked by the $\mathrm{NO}_{3}$ anomalies in Fig. 2e. At the same time the intermediate latitudes of both the Atlantic and Pacific become weaker carbon sinks (Fig. 6 bottom), probably due to the overall shallower carbon turnover resulting in a decreased buffer capacity. Consequently, the typical regions of preindustrial carbon uptake become reduced carbon sinks as marked by the horizontal hatches over blue areas in Fig. 6 top, whereas the major outgassing region in the tropical Pacific is turning into a stronger carbon source, shown by vertical hatches over red background in Fig. 6 top.
BGD

9, 7983-8011, 2012

Modeled $\mathrm{CO}_{2}$ feedbacks

L. A. Bordelon-Katrynski and B. Schneider

Title Page

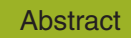

Introduction

Conclusions

Tables

References

Figures

14

-1

4

Back

Close

Full Screen / Esc

Printer-friendly Version

Interactive Discussion 


\section{Discussion}

\subsection{Feedbacks of extra carbon uptake on atmospheric $\mathrm{CO}_{2}$}

In the present study we have used an ocean biogeochemical model to test the hypothesis that a higher $\mathrm{DOC}$ formation rate under elevated atmospheric $\mathrm{CO}_{2}$ concentrations 5 results in an intensification of (particulate) carbon export and thus $\mathrm{CO}_{2}$ drawdown from the surface ocean due to aggregate formation (Arrigo, 2007). However, after quadrupling the DOC exudation rate of phytoplankton, we find a global reduction in particle export $(-4 \%)$ despite an increase in NPP $(+8 \%)$ and surface nitrate due to a shallower turnover of carbon and nutrients. Although the model allows for particle aggregation, and yields indeed higher POC export flux on the borders of the subtopical gyres where DOC accumulates, it obviously does not reach a critical concentration to strengthen particle export at the global scale (Figs. 2, 4). As a result, there is net outgassing of $\mathrm{CO}_{2}$ from the ocean into the atmosphere, providing a positive feedback (Fig. 5). This finding is in contrast to two studies which directly route an above-Redfield carbon uptake into the pool of particulate organic carbon (POC) and thereby strengthen particle export and ocean $\mathrm{CO}_{2}$ uptake (Schneider et al., 2004; Oschlies et al., 2008), and this difference highlights the importance of the actual pathway and thus fate that additional carbon uptake may take.

Tagliabue et al. (2011) use a $\mathrm{CO}_{2}$ sensitivity factor to route an additional amount of 20 fixed carbon (up to $+25 \%$ ) via NPP directly into DOC. Although this is very similar to our approach, where the DOC formation rate (phytoplankton exudation) is increased from 5 to $20 \%$ of carbon fixation (NPP), they find a $4 \%$ stimulation of global carbon export (EP). Apart from potential effects of using different circulation fields, a major difference between the two studies is the overall amount of NPP, which is $49 \mathrm{GtCyr}^{-1}$ in Tagliabue

linking $\mathrm{CO}_{2}$-dependent DOC formation to already higher background NPP, the critical threshold to yield higher particle aggregation and thus EP may have been surpassed. Furthermore, the sensitivity factor used by Tagliabue et al. (2011) prescribes a $25 \%$

BGD

$9,7983-8011,2012$

Modeled $\mathrm{CO}_{2}$ feedbacks

L. A. Bordelon-Katrynski and B. Schneider

\section{Title Page}

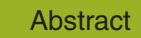

Introduction

Conclusions

Tables

References

Figures

14

4

Back

Close

Printer-friendly Version

Interactive Discussion 
higher NPP at the end of their simulation period, whereas in our study NPP effectively increases only by $8 \%$ (Table 2), representing a lower sensitivity. However, both studies have in common that they result in a reduction of the particle export efficiency (Laws et al., 2000), expressed as the pe-ratio (EP/NPP), on the order of $10 \%$ (see Table 2 5 this study and Table 2 in Tagliabue et al., 2011). In the absence of DIC inventories or cumulative air-sea $\mathrm{CO}_{2}$ exchange from the study by Tagliabue et al. (2011), a reduced pe-ratio can be expected to result in a net loss of $\mathrm{CO}_{2}$ to the atmosphere (Schneider et al., 2008), even though EP may have been strengthened.

A surprising result of our study is the slight apparent $\mathrm{CO}_{2}$ fertilization effect of NPP $10\left(+0.3 \mathrm{GtCyr}^{-1}\right)$ in the combined experiment (CDOC) relative to the DOC only experiment, which is is not found in the $\mathrm{CO}_{2}$ only experiment (Table 2, Fig. 3c, e). This NPP stimulation can be explained by a combination of higher nutrient and iron availability in the experiment CDOC. As it was explained before, the higher nutrient concentrations in the surface ocean are caused by the shallower turnover of organic matter. In addition to 15 this, reduced particle concentrations are lowering the scavenging of iron, which in turn increases iron availability up to $10 \%$ (not shown). In the combined experiment (CDOC) the total particle inventory is reduced by $7 \%$ (Table 2), whereas in the $\mathrm{CO}_{2}$ and DOC experiment there is only a 3-4\% reduction, caused by a lowering of either $\mathrm{PIC}\left(\mathrm{CO}_{2}\right)$ or small and large POC (DOC). A similar $\mathrm{CO}_{2}$ fertilization does not appear in the $\mathrm{CO}_{2}$ 20 only experiment, as here the reduction in particle load is lower than in CDOC and not accompanied by a near surface accumulation of other nutrients such as $\mathrm{NO}_{3}$ (Fig. 2).

The weak iron fertilization effect under ocean acidification also explains why there is a slightly enhanced cumulative carbon uptake in the experiment CDOC relative to $\mathrm{CO}_{2}$ during the first $140 \mathrm{yr}$ of the simulation, with a peak value of $+5 \mathrm{GtC}$ in year 70 (Fig. 5). 25 This transient sink is due to a weakly enhanced carbon uptake in the low latitudes, as it was explained above, which takes several decades to be entrained into the equatorial current system where this extra carbon outgasses again (Fig. 6). The finding that the net outgassing into the atmosphere only becomes active around and after the time
BGD

9, 7983-8011, 2012

Modeled $\mathrm{CO}_{2}$ feedbacks

L. A. Bordelon-Katrynski and B. Schneider

Title Page

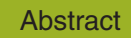

Introduction

Conclusions

Tables

References

Figures

14

$\rightarrow$

4

Back

Close

Printer-friendly Version

Interactive Discussion 
of stabilizing the atmospheric $\mathrm{CO}_{2}$ may also explain why in the study by Tagliabue et al. (2011) the DOC effect may have resulted in a potentially stronger carbon sink.

Since our model is lacking an atmospheric carbon reservoir, the feedback of the simulated net outgassing would in turn represent a positive feedback on the DOC for5 mation, amplifying the response. Consequently, we assume that our model simulation slightly underestimates the feedbacks of enhanced DOC formation on the atmospheric $\mathrm{CO}_{2}$.

\subsection{Implications for future climate change}

Since in our simulation a constant climatological circulation is used, we cannot directly quantify the impact of a stimulated DOC turnover on carbon fluxes in a future warming climate. However, a number of studies exist, which have investigated the impact of climate change on carbon and nutrient cycling in the ocean (Maier-Reimer, 1993, MaierReimer et al., 1996; Sarmiento and Le Quéré, 1996; Sarmiento et al., 1998; Sarmiento and Hughes, 1999; Matear and Hirst, 1999; Friedlingstein et al., 2001, 2006; Schnei15 der et al., 2003; Mckinley et al., 2004, 2006; Gangsto et al., 2008; Gruber et al., 2009; Steinacher et al., 2010; Arnosti et al., 2011). Based on these findings, we can estimate a potential feedback of a $\mathrm{CO}_{2}$ sensitive DOC turnover under global warming. There is consensus that the surface ocean will warm and stratify. This is expected to cause a reduction of NPP due to lower nutrient input into the surface layer (e.g., Kirchman, 20 et al., 2009; Prowe et al., 2009; Steinacher et al., 2010; Trabelsi and Rassoulzadegan, 2011), which would reduce the impact of NPP on DOC formation and thereby the positive feedback found in our study. However, due to an expansion of marine productivity into polar latitudes, mainly as a result of a retraction of sea-ice (Bopp et al., 2001), the DOC feedback would start operating here and thereby it would counteract 25 the low latitude reduction of the positive feedback. Ocean warming is expected to stimulate bacterial activity and thereby the degradation of organic matter, also providing a positive feedback on the atmosphere (Kirchman et al., 2009; Engel et al., 2011). Accordingly, the DOC produced under higher $\mathrm{CO}_{2}$ levels would be even more prone

\section{BGD}

9, 7983-8011, 2012

Modeled $\mathrm{CO}_{2}$ feedbacks

L. A. Bordelon-Katrynski and B. Schneider

Title Page

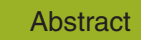

Introduction

Conclusions

Tables

References

Figures

14

$\rightarrow 1$

4

Back

Close

Full Screen / Esc

Printer-friendly Version

Interactive Discussion 
to remineralization, which would amplify the positive feedback found in our study. The situation would be opposite in the high latitudes, where cooler surface waters prevail (Carlson et al., 1998; Laws et al., 2000), so that a stimulation of NPP might result in an overall more efficient carbon export. Apart from the temperature effect, there may also 5 be a direct $\mathrm{CO}_{2}$ impact on bacterial degradation of organic matter (Piontek et al., 2010), which would further amplify the positive feedback of increased DOC turnover. To summarize, under combined future ocean warming, stratification, and ocean acidification a large number of mechanisms come into play, and may either amplify or dampen the positive feedback which was found in our study. Therefore, apart from potential effects 10 of background conditions as discussed above, even the sign of the net response to be expected can not be estimated at present.

\section{Conclusion}

In the present study we simulated a positive feedback of enhanced DOC formation in response to ocean acidification on atmospheric $p \mathrm{CO}_{2}$. Although allowing for particle 15 aggregation, there is a shallower turnover of organic matter and nutrients resulting in a net outgassing of $\mathrm{CO}_{2}$ from the ocean, which does not confirm the hypothesis of higher particle aggregation and thus ocean carbon uptake by Arrigo (2007). A comparison with a very similar study (Tagliabue et al., 2011) highlights the importance of the actual pathway and thus fate the extra carbon takes in the ocean, as well as a potential 20 impact of background conditions such as NPP, to decide whether a higher turnover of DOC would result in a positive or negative feedback. Consequently, further research is needed to systematically analyze the pathway of $\mathrm{CO}_{2}$-stimulated extra carbon uptake in laboratory experiments and model studies.

Acknowledgements. This work was funded by the Federal Ministry of Education and Research 25 (BMBF, FKZ 03F0608M) and the Cluster of Excellence Future Ocean (EXC80/1). We would like to thank Andreas Oschlies, Anke Dürkop and Uta Krebs-Kanzow for their comments that helped to improve the manuscript.

\section{BGD}

9, 7983-8011, 2012

Modeled $\mathrm{CO}_{2}$ feedbacks

L. A. Bordelon-Katrynski and B. Schneider

Title Page

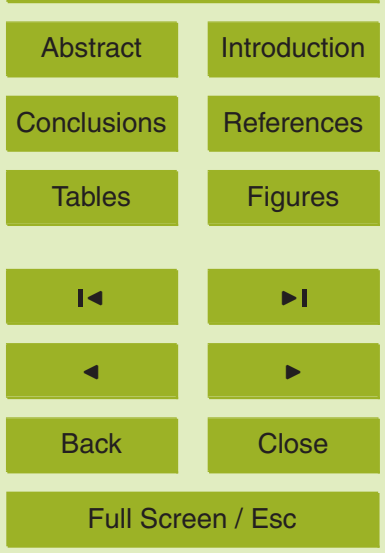

Printer-friendly Version

Interactive Discussion 


\section{References}

Arnosti, C., Steen, A. D., Ziervogel, K., Ghobrial, S., and Jeffrey, W. H.: Latitudinal gradients in degradation of marine dissolved organic matter, PloSONE, 6, 12, doi:10.1371/journal.pone.0028900, 2011.

5 Arrigo, K.: Carbon cycle: marine manipulations, Nature, 450, 491-492, doi:10.1038/450491a, 2007.

Aumont, O. and Bopp, L.: Globalizing results from ocean in situ iron fertilization studies, Global Biogeochem. Cy., 20, 15, doi:10.1029/2005GB002591, 2006.

Behrenfeld, M. J., O'Malley, R. T., Siegel, D. A., McClain, C. R., Sarmiento J. L., Feldman, G. C., Milligan, A. J., Falkowski, P. G., and Letelier, R. M.: Climate-driven trends in contemporary ocean productivity, Nature 444, 752-755, doi:10.1038/nature05317, 2006.

Bopp, L., Monfray, P., Aumont, O., Dufresne. J., Le Treut, H., Madec, G., Terray, L., and Orr, J. C.: Potential impact of climate change on marine export production, Global Biogeochem. Cy., 15,1, 81-99, doi:10.1029/1999GB001256, 2001.

15 Caldeira, K. and Wicket, M. E.: Anthropogenic carbon and pH, Nature, 425, 365, doi:10.1038/425365a, 2003.

Canadell J. G., Le Quéré, C., Raupach, M. R., Field, C. B., Buitenhuis, E. T., Ciasis, P., Conway, T. J., Gillett, N. P., Houghton, R. A., and Marland, G.: Contributions to accelerating atmospheric $\mathrm{CO}_{2}$ growth from economic activity, carbon intensity, and efficiency of natural sinks, PNAS, 104, 47, 18866-18870, 2007.

Carlson, C. A., Bucklow, H. W., Hansell, D. A., and Smith Jr., W. O: Organic carbon partitioning during spring phytoplankton blooms in the Ross Sea polynya and the Sargasso Sea, Limnol. Oceanogr., 43, 375-386, doi:10.4319/lo.1998.43.3.03751998.

Corbière, A., Metzel, N., Reverdin, G., Brunet, C., and Takahashi, T.: Interannual and decadal variability of the oceanic carbon sink in the North Atlantic subpolar gyre, Tellus, 59B, 168178, 2007.

Doney, S. C., Fabry, V. J., Feely, R. A., and Kleypas, J. A.: Ocean Acidification: the other $\mathrm{CO}_{2}$ problem, Ann. R. Mar. Sci., 1, 169-192, 2009.

Dugdale, R. C., and Goering, J. J.: Uptake pf new and regenerated forms of nitrogen in primary

\section{BGD}

9, 7983-8011, 2012

Modeled $\mathrm{CO}_{2}$ feedbacks

L. A. Bordelon-Katrynski and B. Schneider

Title Page

Abstract

Introduction

Conclusions

References

Tables

Figures

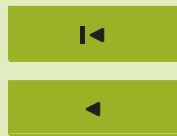

-1

Back

Close

Full Screen / Esc

Printer-friendly Version

Interactive Discussion 
Engel, A., Thoms, S., Reibesell, U., Rochelle-Newall, E., Zondervan, I.: Polysaccharide aggregation as a potential sink of marine dissolved organic carbon, Nature, 428, 929-932, doi:10.1038/nature02453, 2004.

Engel, A., Händel, N, Wohlers, J., Lunau, M., Grossart, H.-P., and Sommer, U.: Effects of sea 5 surface warming on the production and composition of dissolved organic matter during phytoplankton blooms: results from a mesocosm study, J. Plankton Res., 33, 3, 357-372, 2011.

Friedlingstein, P., Bopp, L., and Ciais, P.: Positive feedback between future climate change and the carbon cycle, Geophys. Res. Lett., 28, 8, 1543-1546, 2001.

Friedlingstein, P., Cox, P., Betts, R., Bopp, L., von Bloh, W., Brovkin, V., Cadule, P., Doney, S., Eby, M., Fung, I., Bala, G., John, J., Jones, C., Joos, F., Kato, T., Kawamiya, M., Knorr, W., Lindsay, K., Matthews, H. D., Raddatz, T., Rayner, P., Reick, C., Roeckner, E., Schnitzler, K.G., Schnur, R., Strassmann, K., Weaver, A. J., Yoshikawa C., and Zeng, N.: Climate-carbon cycle feedback analysis: results from the C4MIP model intercomparison, J. Climate, 19, 14, 3337-3353, 2006.

15 Gangsto, R., Gehlen, M., Schneider, B., Bopp, L., and Joos, F.: Modeling the marine aragonite cycle: changes under rising carbon dioxide and its role in shallow water $\mathrm{CaCO}_{3}$ dissolution, Biogeosciences, 5, 1057-1072, doi:10.5194/bg-5-1057-2008, 2008.

Gattuso, P. P., Frankignoulle, M., Bourge, I., Romaine, S., and Buddemeier, R. W.: Effects of calcium carbonate saturation of seawater on coral calcification, Global Planetary Change, $20 \quad 18,37-46,1998$.

Gehlen, M., Bopp, L., Emprin, N., Aumont, O., Heinze, C., and Ragueneau, O.: Reconciling surface ocean productivity, export fluxes and sediment composition in a global biogeochemical ocean model, Biogeosciences, 3, 521-537, doi:10.5194/bg-3-521-2006, 2006.

Gehlen, M., Gangsto, R., Schneider, B., Bopp, L., Aumont, O., and Ethe, C.: The fate of pelagic $\mathrm{CaCO}_{3}$ production in a high $\mathrm{CO}_{2}$ ocean: a model study, Biogeosciences, 4, 505519, doi:10.5194/bgd-4-533-2007, 2007.

Gordillo, F. J. L., Jimenez, C., Figueroa, F. L., and Niell, F. X.: Effects of increased atmospheric $\mathrm{CO}_{2}$ and $\mathrm{N}$ supply on photosynthesis, growth and cell composition of the cyanobacterium Spirulina platensis (Arthrospira), J. Appl. Phycol., 10, 461-469, 1999.

30 Gruber, N., Gloor, M., Mikaloff Flettcher, S. E., Doney, S. C., Dutkiewicz, S., Followes, M. J., Gerber, M., Jacobson, A. R., Joos, F., Lindsay, K., Menemenlis, D., Mouchet, A., Müller, S. A., Sarmiento, J. L., and Takahashi, T.: Oceanic sources, sinks, and transport of atmospheric $\mathrm{CO}_{2}$, Global Biogeochem. Cy., 23, GB1005, 21, doi:10.1029/2008GB003349, 2009.

\section{BGD}

\section{9, 7983-8011, 2012}

Modeled $\mathrm{CO}_{2}$ feedbacks

L. A. Bordelon-Katrynski and B. Schneider

Title Page

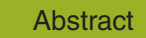

Introduction

Conclusions

References

Tables

Figures

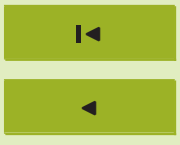

$\rightarrow 1$

Back

Close

Full Screen / Esc

Printer-friendly Version

Interactive Discussion 
Hein, M. and Sand-Jensen, $\mathrm{K} .: \mathrm{CO}_{2}$ increases oceanic primary production, Nature, 388, 526527, 1997.

Hutchins, D. A., Fu, F.-X., Zhang, Y., Warner, M. E., Feng, Y., Portune, K., Bernhardt, P. W., and Mulholland, M. R.: $\mathrm{CO}_{2}$ control of Trichodesmium $\mathrm{N}_{2}$ fixation, photosynthesis, growth

5 rates, and elemental ratios: implications for past, present, and future ocean biogeochemistry, Limnol. Oceanogr., 52, 1293-1304, 2007.

Kanzow, T., Cunningham, S. A., Johns, W. E., Hirschi, J. J.-M., Marotzke, J., Baringer, M. O., Meinen,C. S., Chidichimo, M. P., Atkinson, C., Beal, L. M., Bryden, H. L., and Collins, J.: Seasonal variability of the Atlantic meridional overturning circulation at $26.5^{\circ} \mathrm{N}, \mathrm{J}$. Clim., 23 , 5678-5698, doi:10.1175/2010JCLI3389.1, 2010.

Key, R. M., Kozyr, A., Sabine, C. L., Lee, K., Wanninkhof, R., Bullister, J. L., Feely, R. A., Millero, F. J., Mordyand, C., and Peng, T.-H.: A Global ocean carbon climatology: results from GLODAP, Global Biogeochem. Cy., 18, 23, doi:10.1029/2004GB002247, 2004.

Kirchman, D. L., Moran, X. A. G., and Ducklow, H.: Microbial growth in the polar oceans - role 15 of temperature, and potential impact of climate change, Microbiology, 7, 451-459, 2009.

Laws, E. A., Falkowski, P. G., Smith Jr., W. O., Ducklow, H., and McCarthy, J.: Temperature effects on export production in the open ocean, Global Biogeochem. Cy., 14, 1231-1246, doi:10.1029/1999GB001229, 2000.

Le Quere, C., Raupach, M. R., Canadell, J. G., Marland, G., Bopp, L., Ciais, P., Conway, T. J.,

Le Quéré, C., Raupach, M. R., Canadell, J. G., Marland, G., Bopp, L., Ciais, P., Conway, T. J., Doney, S. C., Feely, R. A., Foster, P., Freidlingstein, P., Gurney, K., Houghton, R. A., House, J. I., Huntingford, C., Levy, P. E., Lomas, M. R., Majkut, J., Metzl, N., Ometto, J. P., Peters, G. P., Presntice, I. C., Randerson, J. T., Running, S., W., Sarmiento J. L., Schuster, U., Sitch, S., Takahashi, T., Viovy, N., vab der Wer, G. R., and Woodward, F. I.: Trends in the sources and sinks of carbon dioxide, Nat. Geosci., 2, 831-836, doi:10.1038/NGEO689, 2009.

Lozier, M. S., Roussenov, V., Reed, M. S. C., and Williams, G.: Opposing decadal changes for the North Atlantic Meridional Overturning circulation, Nat. Geosci., 3, 728-734, doi:10.1038/ngeo947, 2010.

Maier-Reimer, E.: The biological pump in the greenhouse, Global Planetary Climate Change, 8, 13-15, 1993.

\section{BGD}

9, 7983-8011, 2012

Modeled $\mathrm{CO}_{2}$ feedbacks

L. A. Bordelon-Katrynski and B. Schneider

Title Page

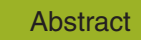

Introduction

Conclusions

References

Tables

Figures

14

$\rightarrow$

4

Back

Close

Full Screen / Esc

Printer-friendly Version

Interactive Discussion 
Maier-Reimer, E., Mikolajewicz, U., and Winguth, A.: Future ocean uptake of $\mathrm{CO}_{2}$ : interaction between ocean circulation and biology, Clim. Dynam., 12, 711-721, 1996.

Matear, R. J. and Hirst, A. C.: Climate change feedback on the future ocean $\mathrm{CO}_{2}$ uptake, Tellus, 51B, 722-733, 1999.

5 McKinley, G. A., Follows, M. J., and Marshall, J.: Mechanisms of air-sea $\mathrm{CO}_{2}$ flux variability in the eqatorial pacific and the North Atlantic, Global Biogeochem. Cy., 18, GB2011, doi:10.1029/2003GB002179, 2004.

McKinley, G. A., Takahashi, T., Buitenhuis, E., Chai, F., Christian, J. R., Doney, S. C., Jiang, M.S., Lindsay, K., Moore, J. K., Le Quéré, C., Lima, I., Murtugudde, R., Shi, L., and Wetzel, P.: North pacific carbon cycle response to climate variability on seasonal to decadal timescales, J. Geophys. Res., 111, C07S06, doi:10.1029/2005JC003173, 2006.

McKinley, G. A., Fay, A. R., Takahashi, T., and Metzl, N.: Convergence of atmospheric and North Atlantic carbon dioxide trends on multidecadal timescales, Nat. Geosci., 4, 606-610, doi:10.1038/NGEO1193, 2011.

Metzl, N., Tilbrook, B., and Poisson, A.:The annual $f \mathrm{CO}_{2}$ cycle and the air-sea $\mathrm{CO}_{2}$ flux in the sub-Antarctic Ocean, Tellus, 51B, 849-861, 1999.

Mikaloff-Fletcher, S. E., Gruber, N., Jacobson, A. R., Gloor, M. N., Doney, S. C., Dutkiewicz, S.,Gerber, M., Follows, M., Joos, F., Lindsay, K., Menemenlis, D., and Mouchet, A.: Inverse estimates of the oceanic sources and sinks of natural $\mathrm{CO} 2$ and the implied oceanic carbon transport, Global Biogeochem. Cy., 21, GB1010, 19, doi:10.1029/2006GB002751, 2007.

Oschlies, A., Schulz, K. G., Riebesell, U., and Schmittner, A.: Simulated 21st century's increase in oceanic suboxia by $\mathrm{CO}_{2}$ enhanced biotic carbon export, Global Biogeochem. Cy., 22, GB4008, 10, doi:10.1029/2007GB003147, 2008.

Passow, U.: Transparent exopolymer particles (TEP) in aquatic environments, Prog. Oceanog., 25 55, 287-333, 2002.

Prowe, A. E. F., Thomas, H., Pätsch, J., Kühn, W., Bozec, Y., Schiettecatte, L.-S., Borges, A. V., and de Baar, $\mathrm{H}$. J. W: Mechanisms controlling the air-sea $\mathrm{CO}_{2}$ flux in the North Sea, Cont. Shelf Res., 29, 15, 1801-1808, doi:10.1016/j.csr.2009.06.003, 2009.

Raven, J. A. and Johnston, A. M.: Mechanisms of inorganic-carbon acquisition in marine phytoplankton and their implications for the use of other resources. Limnol. Oceanogr., 36, 17011714, 1991.

Redfield, A. C., Ketchum, B. H., and Richards, F. A.: The influence of organisms on the composition of sea water, in: The Sea 2 Interscience, Wiley, New York, 26-77, 1963.

BGD

9, 7983-8011, 2012

Modeled $\mathrm{CO}_{2}$ feedbacks

L. A. Bordelon-Katrynski and B. Schneider

Title Page

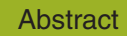

Introduction

Conclusions

References

Tables

Figures

14

$\rightarrow$

4

Back

Close

Full Screen / Esc

Printer-friendly Version

Interactive Discussion 
Riebesell, U., Wolf-Gladrow, D., and Smetacek, V.: Carbon dioxide limitation of marine phytoplankton growth rates, Nature, 361, 249-251, doi:10.1038/361249a0, 1993.

Riebesell, U., Zondervan, I., Rost, B., Tortell, P., Zeebe, R. E., and Morel, F. M. M.: Reduced calcification of marine plankton in response to increased atmospheric $\mathrm{CO}_{2}$, Nature, 407,

5 364-367, 2000.

Riebesell, U., Schulz, K. G., Bellerby, R. G. J., Botros, M., Fritsche, P., Meyerhöfer, M., Neill, C., Nondal, G., Oschlies, A., Wohlers, J., and Zöllner, E.: Enhanced biological carbon consumption in a high $\mathrm{CO}_{2}$ ocean, Nature, 450, 545-548, doi:10.1038/nature06267, 2007.

Roy, T., Bopp, L., Gehlen, M., Schneider, B., Cadule, P., Frölicher, T. L., Segschneider, J., Tjiputra, J., Heinze, C., and Joos, F.: Regional impacts of climate change and atmospheric $\mathrm{CO}_{2}$ on future ocean carbon uptake: a multi-model linear feedback analysis, J. Climate, 24, 23002318, 2011.

Sabine, C. L., Feely, R. A., Gruber, N., Key, R. E., Lee, K., Bullister, J. L., Wanninkhof, R., Wong, C. S., Wallace, D. W. R., Tilbrook, B., Millero, F. J., Peng, T. H., Kozyr, A., Ono, T., and Rios, A.: The oceanic sink for anthropogenic $\mathrm{CO}_{2}$, Nature, 305, 367-371, doi:10.1126/science.1097403, 2004.

Sarmiento, J. L. and Hughes, T. M. C.: Anthropogenic $\mathrm{CO}_{2}$ uptake in a warming ocean, Tellus, 51B, 560-561, 1999.

Sarmiento, J. L. and Le Quéré, C.: Oceanic carbon dioxide uptake in a model of century-scale global warming, Science, New Series, 274, 1346-1350, 1996.

Sarmiento, J. L., Hughes, T. M. C., Stouffer, R. J., and Manabe, S.: Simulated response of the ocean carbon cycle to anthropogenic climate change, Nature, 393, 245-249, doi:10.1038/30455, 1998.

Schmitz, W. J. and McCartney, M. S.: On the North Atlantic Circulation, Rev. Geophys., 1, 29-49, 1993.

Schneider, B., Engle, A., and Schlitzer, R.: Effects of depth- and $\mathrm{CO}_{2}$-dependent C:N ratios of particulate organic matter (POM) on the marine carbon cycle, Global Biogeochem. Cy., 18, GB2015, 13, doi:10.1029/2003GB002184, 2004.

Steinacher, M., Joos, F., Frölicher, T. L., Bopp, L., Cabule, P., Cocco, V., Doney, S. C., Gehlen, M., Lindsay, K., Moore, J. K., Schneider, B., and Segschneider, J.: Projected 21st century decrease in marine productivity: a multi-model analysis, Biogeosciences, 7, 9791005, doi:10.5194/bgd-6-7933-2009, 2010.

\section{BGD}

9, 7983-8011, 2012

Modeled $\mathrm{CO}_{2}$ feedbacks

L. A. Bordelon-Katrynski and B. Schneider

Title Page

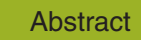

Introduction

Conclusions

References

Tables

Figures

14

$\rightarrow$

4

Back

Close

Full Screen / Esc

Printer-friendly Version

Interactive Discussion 
Stramma, L., Brandt, P., Schafstall, J., Schott, F., Fischer, J., and Kortinger, A.: Oxygen minimum zone in the North Atlantic south and east of the Cape Verde Islands, J. Geophys. Res., 113, C04014, 15, doi:10.1029/2007JC004369, 2008.

Tagliabue, A., Bopp, L., and Gehlen, M.: The response of marine carbon and nutrient cycles to 5 ocean acidification: large uncertainties related to phytoplankton physiological assumptions, Global Biogeochem. Cy., 25, GB3017, doi:10.1029/2010GB003929, 13, 2011.

Takahashi, T., Sutherland, S. C., Sweeney, C., Poisson, A., Metzl, N., Tilbrook, B., Bates, N., Wanninkhof, R., Feely, R. A., Sabine, C., Olafsson, J., and Nojiri, Y.: Global sea-air $\mathrm{CO}_{2}$ flux based on climatological surface ocean $p \mathrm{CO}_{2}$, and seasonal biological and temperature effects, Deep-Sea Res. Pt. II, 49, 1601-1622, 2002.

Takahashi, T., Sutherland, S. C., Wanninkhof, R., Sweeney, C., Feely, R. A., Chipman, D. W., Hales, B., Friederich, G., Chavez, F., Watson, A., Bakker, D. C. E., Schuster, U., Metzl, N., Yoshikawa-Inoue, H., Ishii, M., Midorikawa, T., Nojiri, Y., Sabine, C., Olafsson, J., Arnarson, T. S., Tilbrook, B., Johannessen, T., Olsen, A., Bellerby, R., Körtzinger, A., Steinhoff, T., Hoppema, M., de Baar, H. J. W., Wong, C. S., Delille B., and Bates, N. R.: Climatological mean and decadal changes in surface ocean $p \mathrm{CO}_{2}$, and net sea-air $\mathrm{CO}_{2}$ flux over the global ocean, Deep-Sea Res. Pt. II, 56, 554-577, 2009.

Talley, L. D., Reid, J. L., and Robbins, P. E.: Data-based meridional overturning streamfunctions of the global ocean, J. Climate, 16, 3213-3226, 2003.

20 Tomczak, M. and Godfrey, J. S.: Hydrology of the Atlantic Ocean, in: Regional Oceanography: an Introduction, 2 Edn., Butler and Tanner Ltd, London, England, 253-269, 2003.

Trabelsi, A. and Rassoulzadegan, F.: Effect of bacterial community dynamics on DOC seasonal changes in the North-western Mediterranean Sea, J. Plankton Res., 33, 8, 1249-1262, 2011.

Volk, T. and Hoffert, M. I., Ocean carbon pumps: analysis of relative strengths and efficiencies in ocean-driven atmospheric $\mathrm{CO}_{2}$ changes, in: The Carbon Cycle and Atmospheric $\mathrm{CO}_{2}$ : Natural Variations Archean to Present, Geophys. Monogr. Ser., 32, edited by: E. T. Sundquist and W. S. Broecker, AGU, Washington, D.C., 99-110, 1985.

\section{BGD}

9, 7983-8011, 2012

Modeled $\mathrm{CO}_{2}$ feedbacks

L. A. Bordelon-Katrynski and B. Schneider

Title Page

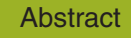

Introduction

Conclusions

References

Tables

Figures

14

$\rightarrow 1$

4

Back

Close

Full Screen / Esc

Printer-friendly Version

Interactive Discussion 
BGD

9, 7983-8011, 2012

Modeled $\mathrm{CO}_{2}$ feedbacks

L. A. Bordelon-Katrynski and B. Schneider

Table 1. Overview of the experiments, which were initialized from a $6000 \mathrm{yr}$ spinup. The idealized scenarios for both $\mathrm{CO}_{2}$ and DOC production follow a $1 \%$ increase rate per year, resulting in a doubling after $70 \mathrm{yr}$ and a quadrupling after $140 \mathrm{yr}$, respectively. Beyond the year $140 \mathrm{CO}_{2}$ and DOC formation are stabilized at the quadrupled value until the end of the simulation (model year 500).

\begin{tabular}{lcc}
\hline Experiment & Atmospheric $\mathrm{CO}_{2}$ & DOC production \\
\hline Control & preindustrial 284.6ppm & constant 0.05 \\
CDOC & $1-4 \times \mathrm{CO}_{2}+$ stab. & $1-4 \times \mathrm{DOC}+$ stab. \\
$\mathrm{CO}_{2}$ & $1-4 \times \mathrm{CO}_{2}+$ stab. & constant 0.05 \\
$\mathrm{DOC}$ & preindustrial $284.6 \mathrm{ppm}$ & $1-4 \times \mathrm{DOC}+$ stab. \\
\hline
\end{tabular}

Title Page

Abstract Introduction

Conclusions References

Tables

Figures

14

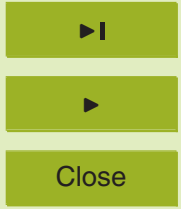

Back

Close

Full Screen / Esc

Printer-friendly Version

Interactive Discussion 


\section{BGD}

9, 7983-8011, 2012

\section{Modeled $\mathrm{CO}_{2}$ feedbacks}

L. A. Bordelon-Katrynski and B. Schneider

Table 2. Global values of key biogeochemical variables in the different experiments. Particle export (EP) is the flux of particulate organic matter across $100 \mathrm{~m}$ depth. The average surface nitrate concentrations are calculated for the top $100 \mathrm{~m}$ of the water column. All inventories quantify global standing stocks, whereby the opal inventory is expressed in carbon units, to be comparable with the other particle types.

\begin{tabular}{lcccccccccc}
\hline Experiments & $\begin{array}{c}\text { NPP } \\
(\mathrm{GtC})\end{array}$ & $\begin{array}{c}\text { NPP } \\
\text { Diatoms } \\
(\mathrm{GtC})\end{array}$ & $\begin{array}{c}\text { NPP } \\
\text { Nanophyto. } \\
(\mathrm{GtC})\end{array}$ & $\begin{array}{c}\mathrm{EP} \\
(\mathrm{GtC})\end{array}$ & $\begin{array}{c}\text { surf. } \mathrm{NO}_{3} \\
\left(\mu \mathrm{ml}^{-1}\right)\end{array}$ & $\begin{array}{c}\mathrm{DOC} \\
\text { Inv. } \\
(\mathrm{GtC})\end{array}$ & $\begin{array}{c}\mathrm{DIC} \\
\text { Inv. } \\
(\mathrm{GtC})\end{array}$ & $\begin{array}{c}\mathrm{POC} \\
\text { Inv. } \\
(\mathrm{GtC})\end{array}$ & $\begin{array}{c}\mathrm{PIC} \\
\text { Inv. } \\
(\mathrm{GtC})\end{array}$ & $\begin{array}{c}\text { Opal } \\
\text { Inv. } \\
(\mathrm{GtC})\end{array}$ \\
\hline Control & 36.6 & 6.83 & 29.8 & 7.44 & 5.85 & 43.3 & 35963 & 1.11 & 0.07 & 0.11 \\
$\mathrm{CDOC}$ & 39.7 & 7.50 & 32.2 & 7.10 & 6.16 & 43.9 & 37908 & 1.07 & 0.02 & 0.11 \\
$\mathrm{CO}_{2}$ & 36.6 & 6.86 & 29.7 & 7.45 & 5.83 & 43.4 & 37945 & 1.11 & 0.02 & 0.11 \\
$\mathrm{DOC}$ & 39.5 & 7.40 & 32.1 & 7.12 & 6.15 & 43.8 & 35935 & 1.07 & 0.07 & 0.11 \\
\hline
\end{tabular}

Title Page

Abstract Introduction

Conclusions References

Tables Figures

14

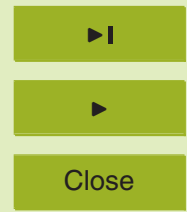

Back

\section{Full Screen / Esc}

Printer-friendly Version

Interactive Discussion 


\section{Figure 1}

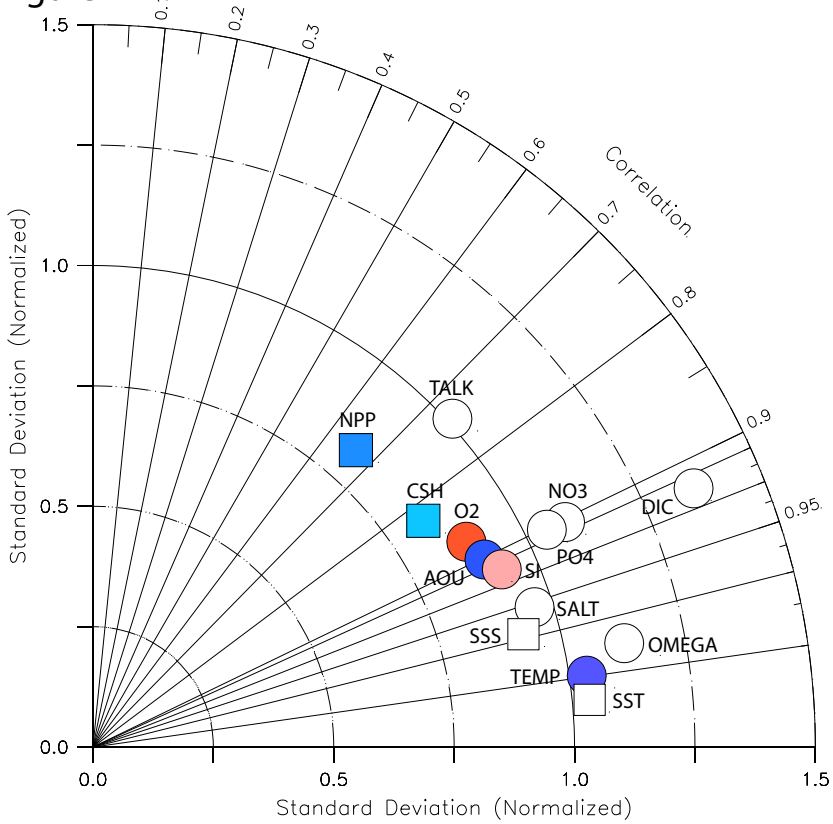

Fig. 1. Taylor Diagram showing the agreement of the spatial distribution of physical and ocean biogeochemical variables from the model and observations. A perfect match between both would lie at the origin of the plot $(1,1$ point at the bottom). The color scale indicates the modeldata bias, expressed as the ratio of global average values (model/data). 2-D variables are shown as squares and 3-D variables as circles. Data sources are as follows: oxygen $\left(\mathrm{O}_{2}\right)$, silica (SI), apparent oxygen utilization (AOU), phosphate $\left(\mathrm{PO}_{4}\right)$, nitrate $\left(\mathrm{NO}_{3}\right)$, sea surface temperature (SST), sea surface salinity (SSS), temperature (TEMP), salinity (SALT) are from the World Ocean Atlas (Collier and Durack, 2006); depth of the calcite saturation horizon (CSH), degree of calcite saturation (Omega), total alkalinity (TALK) and dissolved inorganic carbon (DIC) are from Glodap data (Key et al., 2004), net primary production (NPP) is from Behrenfeld et al. (2006).

\section{BGD}

9, 7983-8011, 2012

\section{Modeled $\mathrm{CO}_{2}$ feedbacks}

L. A. Bordelon-Katrynski and B. Schneider

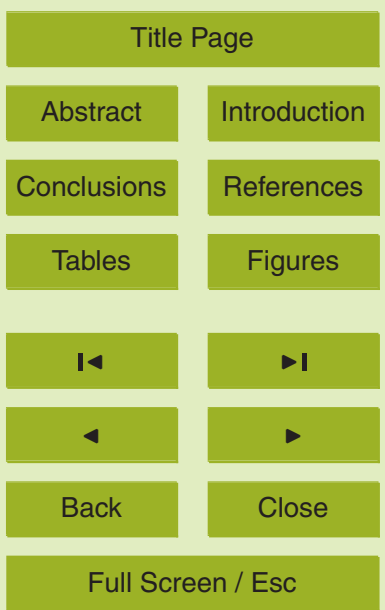

Printer-friendly Version

Interactive Discussion 


\section{Figure 2 Pacific}

Atlantic
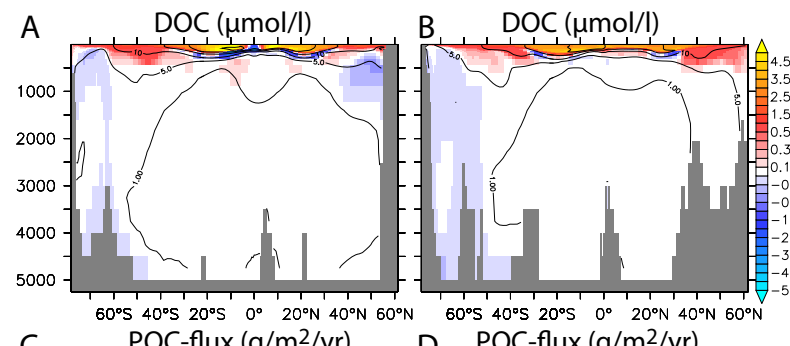

C

POC-flux $\left(\mathrm{g} / \mathrm{m}^{2} / \mathrm{yr}\right)$

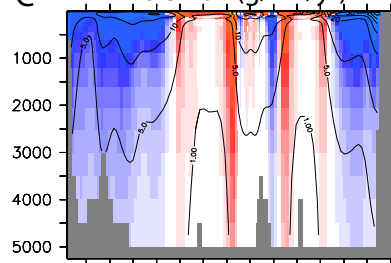

每 $20^{\circ} \mathrm{N} 40^{\circ} \mathrm{N} 60^{\circ} \mathrm{N}$
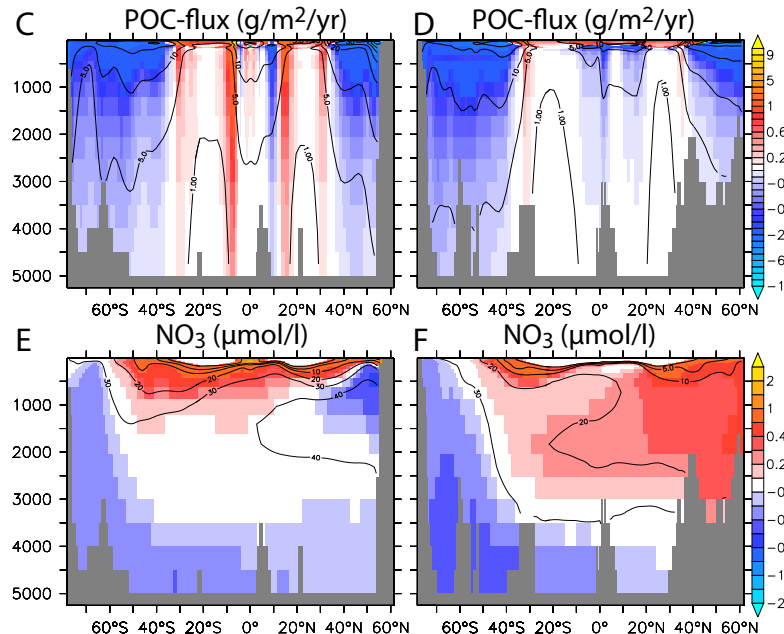

$\mathrm{F}$

$\mathrm{NO}_{3}(\mu \mathrm{mol} / \mathrm{l})$

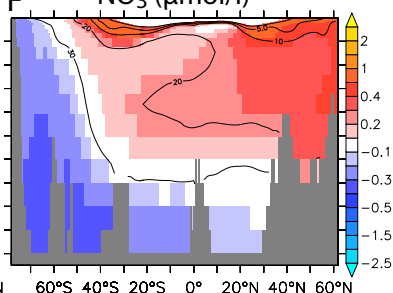

Fig. 2. North-south transects across the Pacific at $160^{\circ} \mathrm{W}$ (A,C,E) and the Atlantic at $25^{\circ} \mathrm{W}$ (B,D,F) showing differences between the experiment CDOC and the control (CDOC-control) of DOC concentrations $(\mathbf{A}, \mathrm{B}), \mathrm{POC}$-flux $(\mathbf{C}, \mathbf{D})$, and $\mathrm{NO}_{3}$ concentrations $(\mathbf{E}, \mathrm{F})$. The contours in each plot indicate absolute values from the control run.
BGD

9, 7983-8011, 2012

Modeled $\mathrm{CO}_{2}$ feedbacks

L. A. Bordelon-Katrynski and B. Schneider

\section{Title Page}

Abstract Introduction

Conclusions

References

Tables

Figures

14

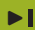

4

\section{Back}

Close

\section{Full Screen / Esc}

Printer-friendly Version

Interactive Discussion 


\section{BGD}

9, 7983-8011, 2012

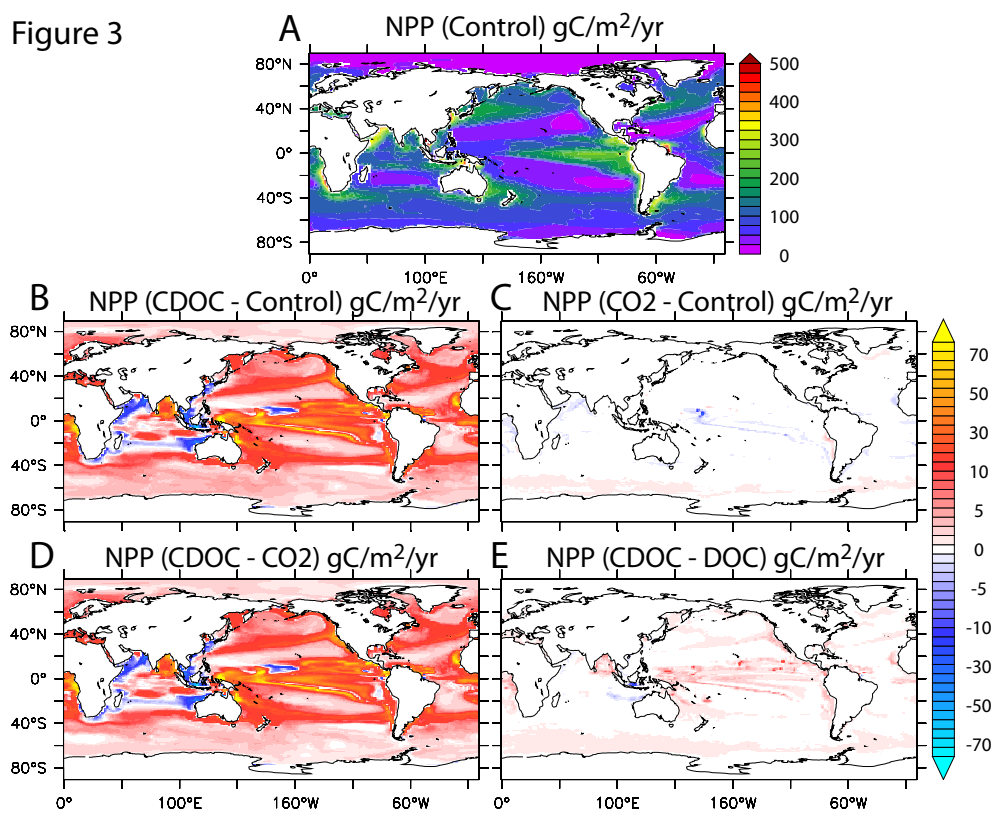

\section{Modeled $\mathrm{CO}_{2}$ feedbacks}

L. A. Bordelon-Katrynski and B. Schneider

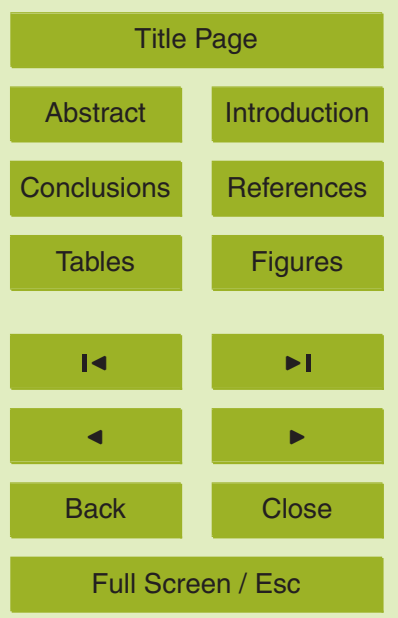

Fig. 3. Global Maps of NPP $\left(\mathrm{g} \mathrm{m}^{-2} \mathrm{yr}^{-1}\right)$ and the effects of different mechanisms on NPP: (A) total NPP in the control run; (B) CDOC-Control, showing the combined effect of increased DOC formation and $\mathrm{CO}_{2}$ on NPP; (C) $\mathrm{CO}_{2}$-Control, confirming that there is no direct effect of $\mathrm{CO}_{2}$ on NPP; (D) CDOC- $\mathrm{CO}_{2}$, isolating the pure DOC effect on NPP at high $\mathrm{CO}_{2}$, (E) CDOC-DOC, highlighting a small positive impact of $\mathrm{CO}_{2}$ on NPP under high DOM formation.

Printer-friendly Version

Interactive Discussion 


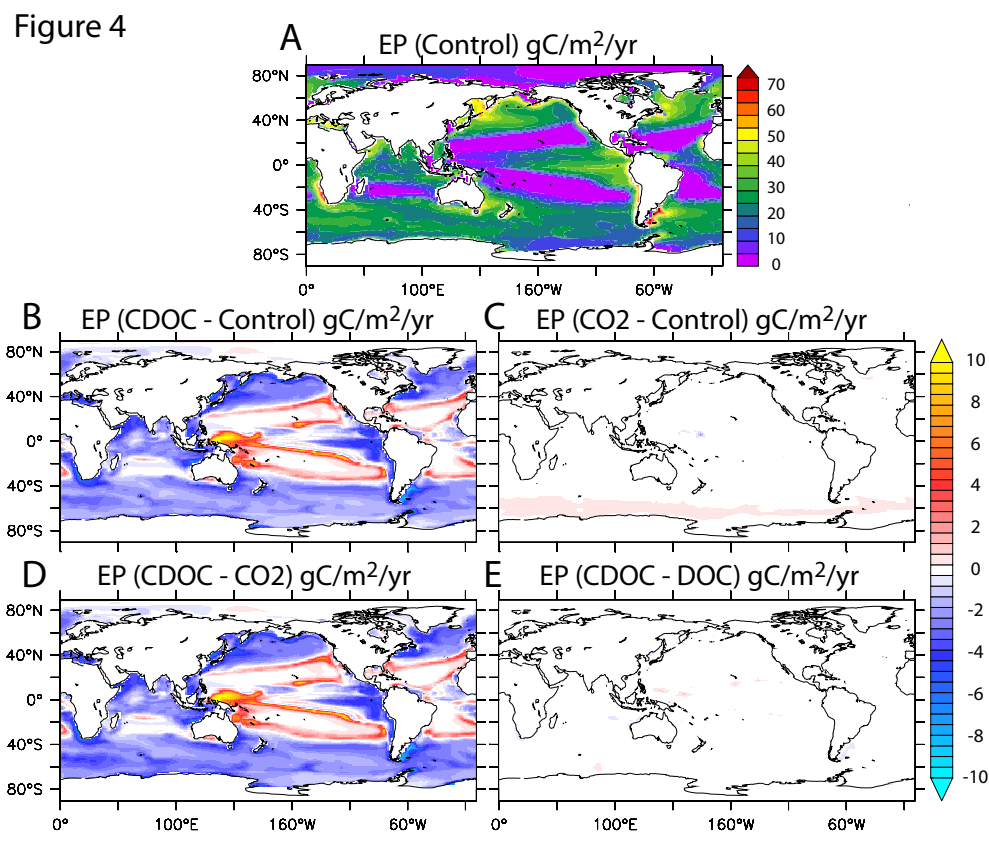

Fig. 4. Global Maps of EP $\left(\mathrm{g} \mathrm{m}^{-2} \mathrm{yr}^{-1}\right)$ and the effects of different mechanisms on EP: (A) total EP in the control run; (B) CDOC-Control, highlighting the full effect of increased DOC formation and $\mathrm{CO}_{2}$ on $\mathrm{EP}$; (C) $\mathrm{CO}_{2}$-Control, indicating a minor $\mathrm{CO}_{2}$-stimulated EP increase in the Southern Ocean, which does not contribute significantly to the global integral (Table 2); (D) CDOC- $\mathrm{CO}_{2}$, showing very similar values as in (B); (E) CDOC-DOC, showing that in contrast to NPP there is no effect of $\mathrm{CO}_{2}$ on EP under high DOC formation.
BGD

9, 7983-8011, 2012

\section{Modeled $\mathrm{CO}_{2}$ feedbacks}

L. A. Bordelon-Katrynski and B. Schneider

\section{Title Page}

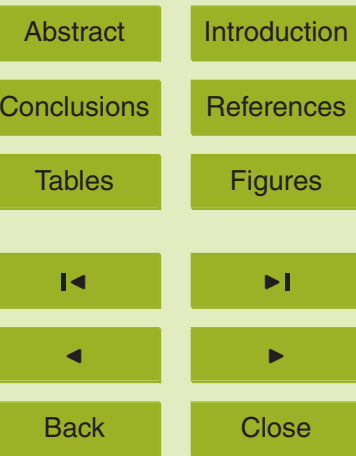

Full Screen / Esc

Printer-friendly Version

Interactive Discussion 


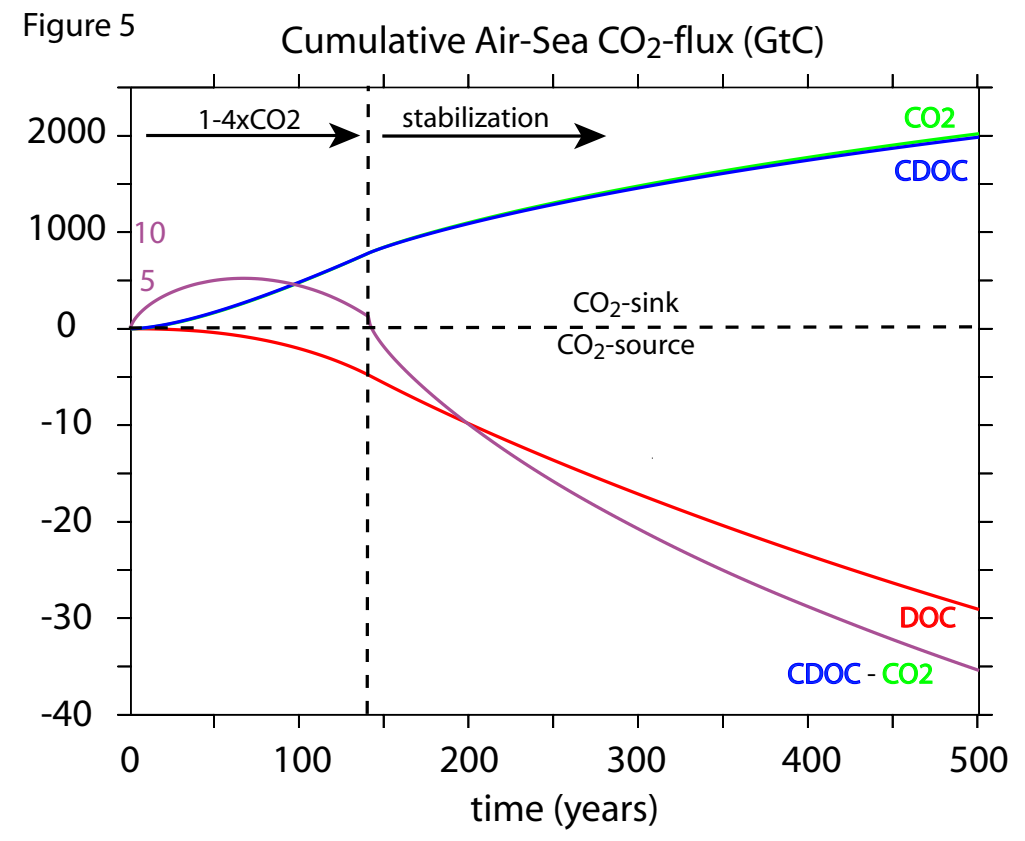

Fig. 5. Cumulative global air-sea $\mathrm{CO}_{2}$ flux in all experiments. Note that the negative part of the vertical axis, which is indicating an oceanic $\mathrm{CO}_{2}$ source, is of a smaller scale than the positive part. The purple line shows the effect of high $\mathrm{DOC}$ formation at high $\mathrm{CO}_{2}\left(\mathrm{CDOC}-\mathrm{CO}_{2}\right)$. Please note, that for the small $\mathrm{CO}_{2}$ sink in the first $140 \mathrm{yr}$ as indicated by the purple line, the scale is given in purple on the left.
BGD

9, 7983-8011, 2012

\section{Modeled $\mathrm{CO}_{2}$ feedbacks}

L. A. Bordelon-Katrynski and B. Schneider

\section{Title Page}

Abstract

Introduction

Conclusions

References

Tables

Figures

14

4

Back

Close

\section{Full Screen / Esc}

Printer-friendly Version

Interactive Discussion 


\section{Figure 6}

Sea-Air $\mathrm{CO}_{2}$ flux (Control) gC/m2/yr
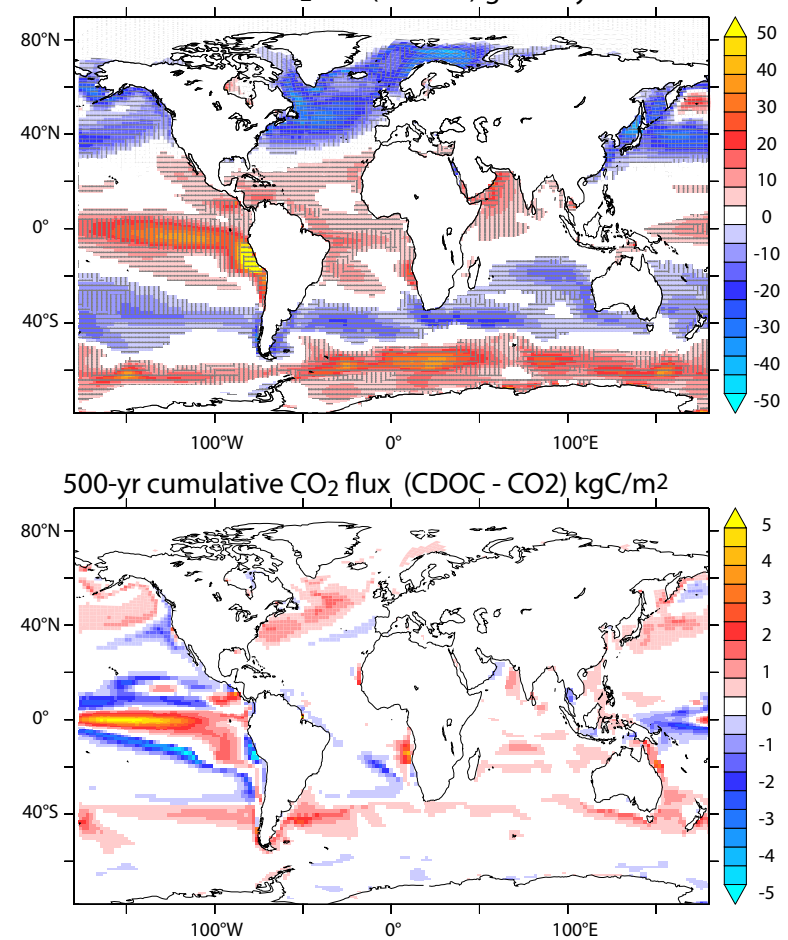

Fig. 6. Sea-air $\mathrm{CO}_{2}$ flux cumulated over the $500 \mathrm{yr}$ of the control simulation (top). Blue colors indicate $\mathrm{CO}_{2}$ uptake by the ocean, red colors show outgassing. The difference between cumulative $\mathrm{CO}_{2}$ fluxes in the $\mathrm{CDOC}$ experiment and the $\mathrm{CO}_{2}$ experiment $\left(\mathrm{CDOC}-\mathrm{CO}_{2}\right)$ is shown at the bottom. Here blue colors mark regions of intensified sink or weakened ourgassing, while red colors highlight areas of weaker ocean uptake or stronger outgassing. A DOC-induced intensification of either sources or sinks is shown in the top panel by overlaid vertical hatches, whereas dampened sources/sinks are marked by horizontal hatches.

\section{BGD}

\section{9, 7983-8011, 2012}

\section{Modeled $\mathrm{CO}_{2}$ feedbacks}

L. A. Bordelon-Katrynski and B. Schneider

Title Page

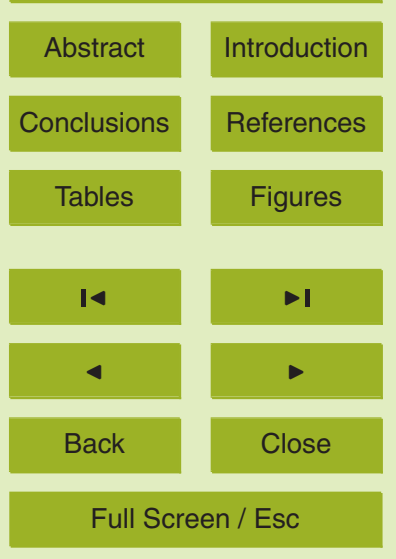

Printer-friendly Version

Interactive Discussion 